\title{
Gold Usage and the Patent World
}

\author{
USE OF PATENTS AS A SOURCE OF TECHNOLOGICAL INFORMATION ON GOLD
}

\author{
Oskar A. Kunze \\ International Gold Corporation, Johannesburg, South Africa.
}

\begin{abstract}
This article is not intended to be exhaustive either with regard to the featuring of gold in the patent literature, or in respect of patents, patent laws and their implications. The aim of the article is to review some of the interesting and informative facts encountered by the Intergold Information Service in compiling its bibliographic data bank on industrial gold uses and properties, and in publishing the review 'Gold Patent Digest'; perhaps this contribution might aid others searching the literature on gold industrial usage.
\end{abstract}

Recently the author had cause to order through the Intergold New York office a copy of a U.S. Government Patent Application relating to the use of gold in electronics. The reply telex read: "The U.S. Government considers this patent as proprietary information and will not release any information on it'. Shortly afterwards it was realised that the complete patent specification of this invention had already been published and had in fact recently come into our possession.

This is not an isolated case of the type of confusion reigning in the information service world regarding protection rights. In a recent issue of New Scientist similar examples are given under the heading 'Details of 'secret' patents published' (1). These incidents are indicative of the wide-spread misconceptions which exist about patents and patent laws, of which secrecy is one. As a matter of fact, the very basis on which patent laws are built excludes any possibility of secrecy surrounding patent publications (indeed the word 'patent' derives from the Latin 'patere', meaning lay open to the public). This of course, does not exclude the existence of nebulous formulations in patents. However, it is doubtful that these could stand up in court to the rigours of litigation.

What are the patent laws? Their roots go back through centuries and the essence of the patent system is magnificently worded in an 1851 edict of the Austria-Hungarian Monarchy:

'The reform of the Empire makes it necessary to introduce laws for the stimulation of the inventive spirit in industry in these parts of the empire which hitherto had no such protection' (2).

\section{Stimulation and Protection}

How do patent laws stimulate and protect the inventive spirit? The intention is to achieve this by granting the inventor special rights regarding the exploitation of his invention in exchange for a total disclosure of the invention, i.e. making it available to the general public in order to stimulate the advent of better inventions. Thus, patent documents are readily available to everybody, and as far as the author could establish, no copyright protection exists for patent publications. It is therefore evident that should anybody wish to keep an invention secret, he may not resort to the patent system.

\section{Patents, Yesterday and Today}

The writer recently had the opportunity to search a unique collection of old patent documents, the collection of 90000 'privileges' (Privilegien) from the years 1852 to 1899 at the Austrian
Patent Office in Vienna, for those which relate to gold usage. Some of these old patents (or privileges) are most interesting for historical reasons, and others demonstrate the essence of patent documentation in a more eloquent and picturesque way than do many modern releases. This is ably revealed in the example quoted below.

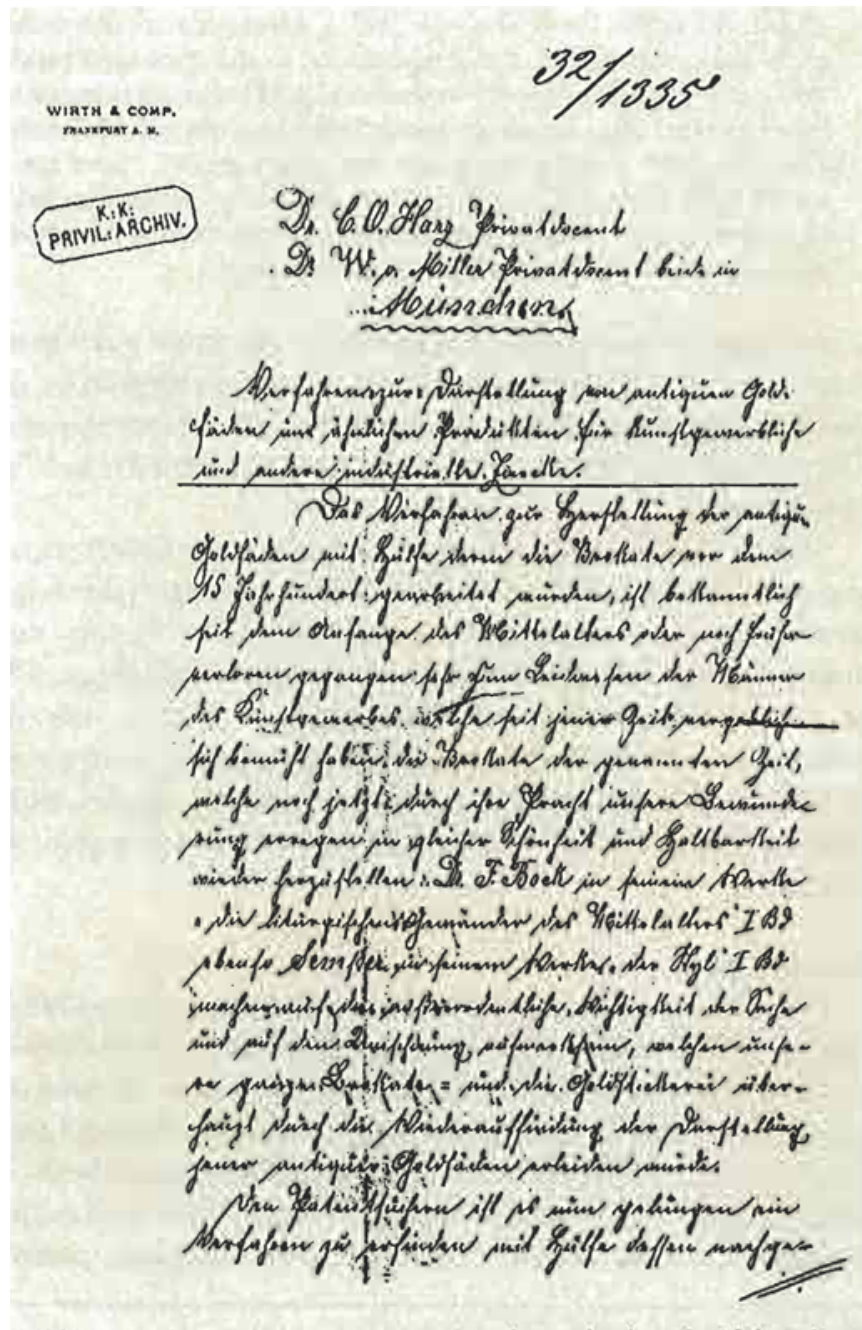

Fig. 1 Austrian Privilege 32/1335 (1882) on the production of gold threads. 
Most patent documents contain ample information besides the description of the actual invention. Being a review of the prior art in its field, the patent is concerned with the reasons why the invention is adding something new to that field. This srructure, which can be found in most patent publicarions, is beautifully illustrated in Figure $1^{*}$ above, which shows rhe first page of privilege number $32 / 1335$ granted in 1882 , to Drs. C.O. Harz and W. von Miller, both of Munich. The document describes a 'Method for' the Production of Antique Gold Threads and Similar Products for Arts and Crafts and Orher Industrial Purposes', and is approximately translated as follows:

'As is well known, the technique of producing antique gold threads which were used in the working of brocades prior to the 15 th century, has been lost since the beginning of the Middle Ages, or even earlier, this causing great distress to the men of arts and crafts since those times who have endeavoured in vain to recreate in their original beauty and durability these brocades, which even today compel our admiration by their splendour. Dr. F. Bock, in his books 'The Liturgical Robes of the Middle Ages', Vol. 1 and 'The Style', Vol. 1, draws our attention to the exceptional importance of this matter, and to the revolution which would take place in our entire brocade and gold embroidery industry by a rediscovery of the fabrication methods of these antique gold threads. The applicants (literally translated 'the patent seekers') have been successful in inventing a method which, as has been proved, can help in recreating gold threads of the same beauty and durability as those of the above-mentioned brocades of ancient times.'

It follows a method which essentially is the impregnarion of animal membranes such as bladders or intestines with gold foil or powder or by galvanic means, and these are then cut into threads. The privilege structurc is quite clear: Background, Prior Art and the Novel Process.

That this process was not so novel at the time is evident from an annexure (Figure 2) which states that, in 1885, the larger part of this patent, due to a complaint by a Theodor Graf of Vienna, was nullified, save for the parts which involve the electrolytic deposition of metal. However this privilege, whether valid or invalid, demonstrates the relatively standardized information pattern which is offered also by today's patents and patent applications, independent of whether or not a patent for the latter will be granted eventually.

\section{Counterfeits}

Gold, because of its value, has always been subject to fraud and forgery, and devices for derecting counterfeits of coins have thus of necessity been the subject of invention. Descriptions of those of yesterday and today make an interesting comparison. Figures 3 and 4 show two patent documents, dated over 100 years apart, both of which disclose devices which allow the detection of fake gold coins: Austrian Privilege VIII-409 of 1876 and European patent

*Reproduction of 'privileges' with the kind permission of the Austrian Patent Office.

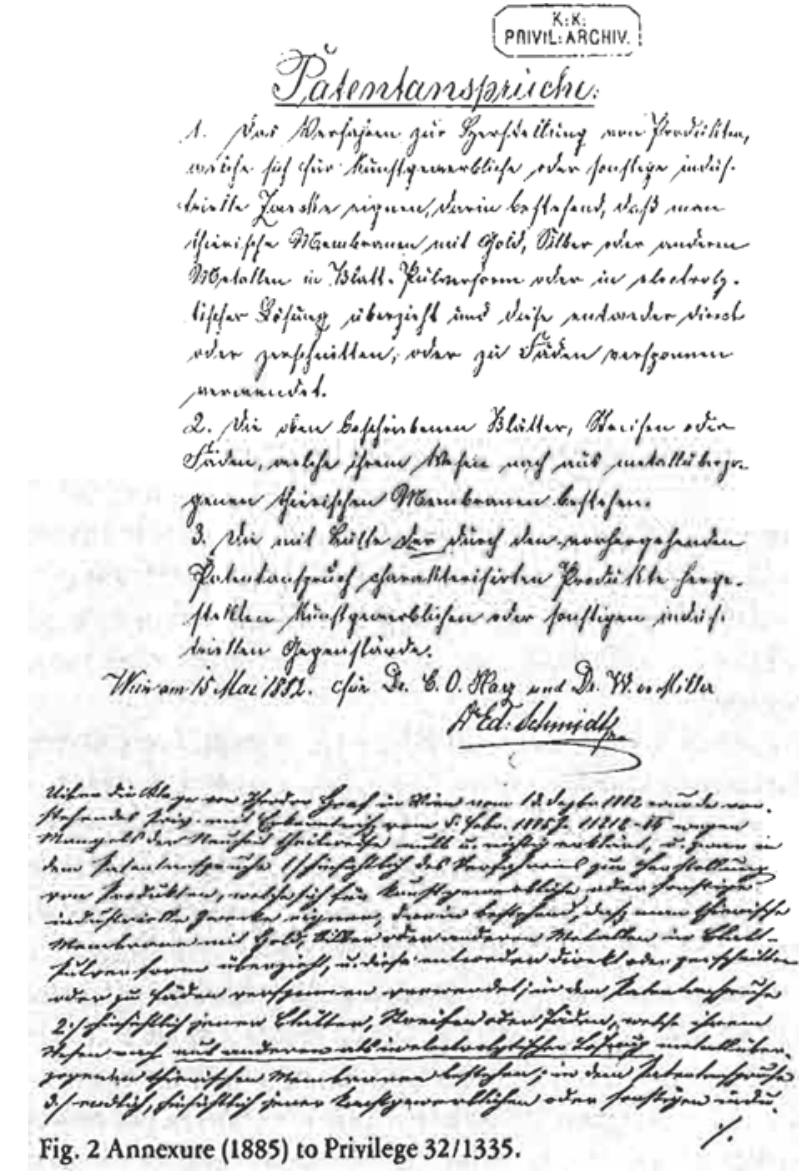

application EP 113031 of 1984. A considerable difference in methods of operation is apparent: the former tests size and mass of coins, the latter the resonance frequencies of coins and bars. Another interesting difference, however, is found in the introductory justification for the necessity for such instrumentation. The underlying reasons are given in similar manner in both documents, but it is the psychological aspect evident in the old patent which is fascinating. Not only is this inspection procedure constructed to examine the authenticity of coins, but one important aspect is that in the older patent this is to be done in a clandestine manner, undetected by the customer, in order not to reveal any suspicion:

"The device has the purpose of offering to the public a convenient method of checking any accepted gold coin rapidly for its authenticity and proper weight without the necessity of resorting to the gold scale which is not in common use in daily business transactions because it reveals suspicion, and it is time-consuming'.

Thus the described device had a slot from which authentic coins rolled into the cash box, and only fake coins were ejected into an open container, raising suspicion only when justified. 


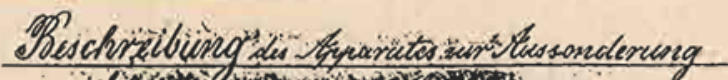

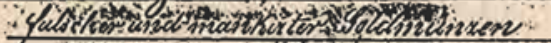

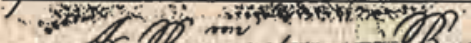

bis o int

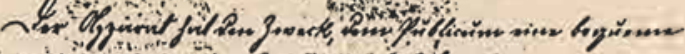

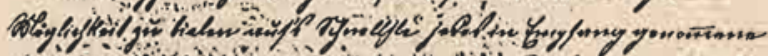

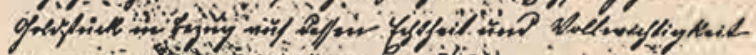

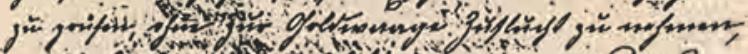

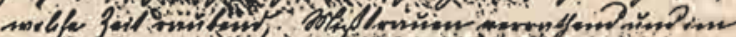
lin

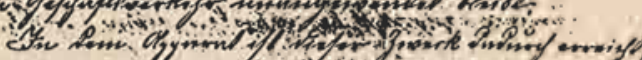

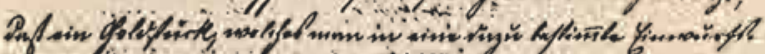

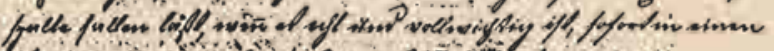

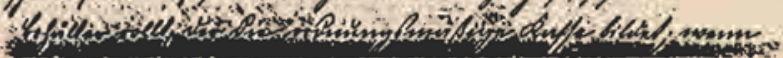

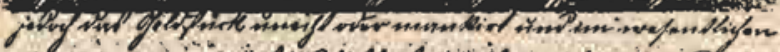

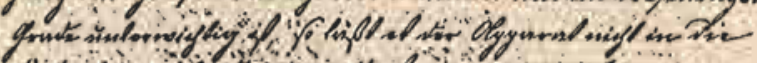

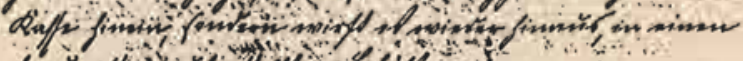

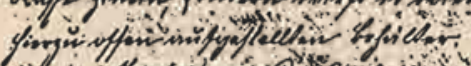

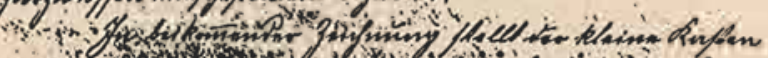

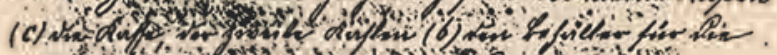

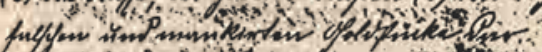

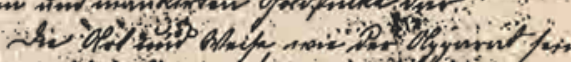

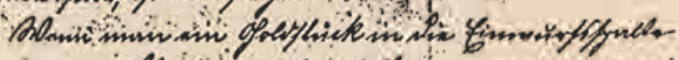

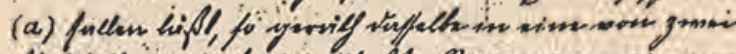

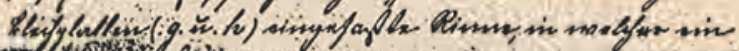

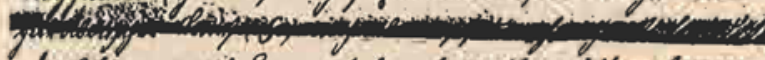

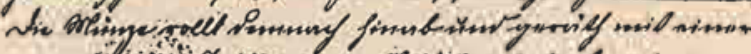

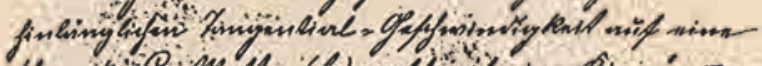

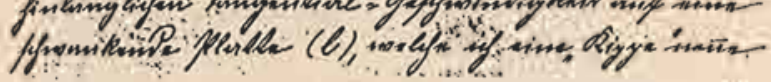

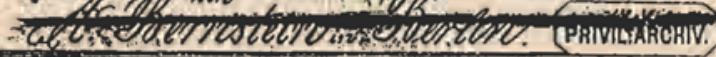

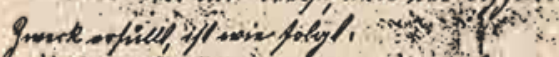

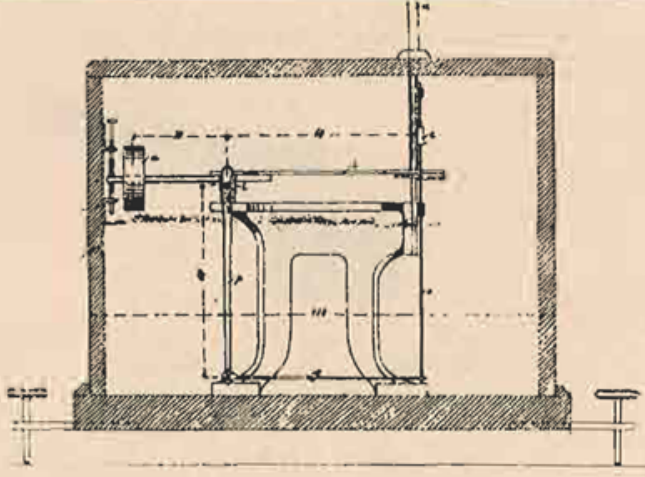

Wasjustab rh.

\section{Vorrichtung}

xum Sortiven oon Goldmü̈nzen.

$$
\text { wose }
$$

\section{Beristem in bertin}

Ayparat fuir-20 Nark-SYücke.

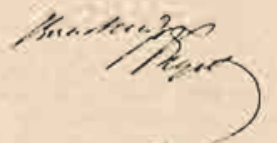

Fig. 3 (Above): First page and diagram from 1876 Austrian Privilege claiming the testing of size and mass of coins for the detection of fakes.

Fig. 4 (Right): Diagram from modern patent (1984) claiming resonance frequency testing of gold coins and bars to establish authentication.

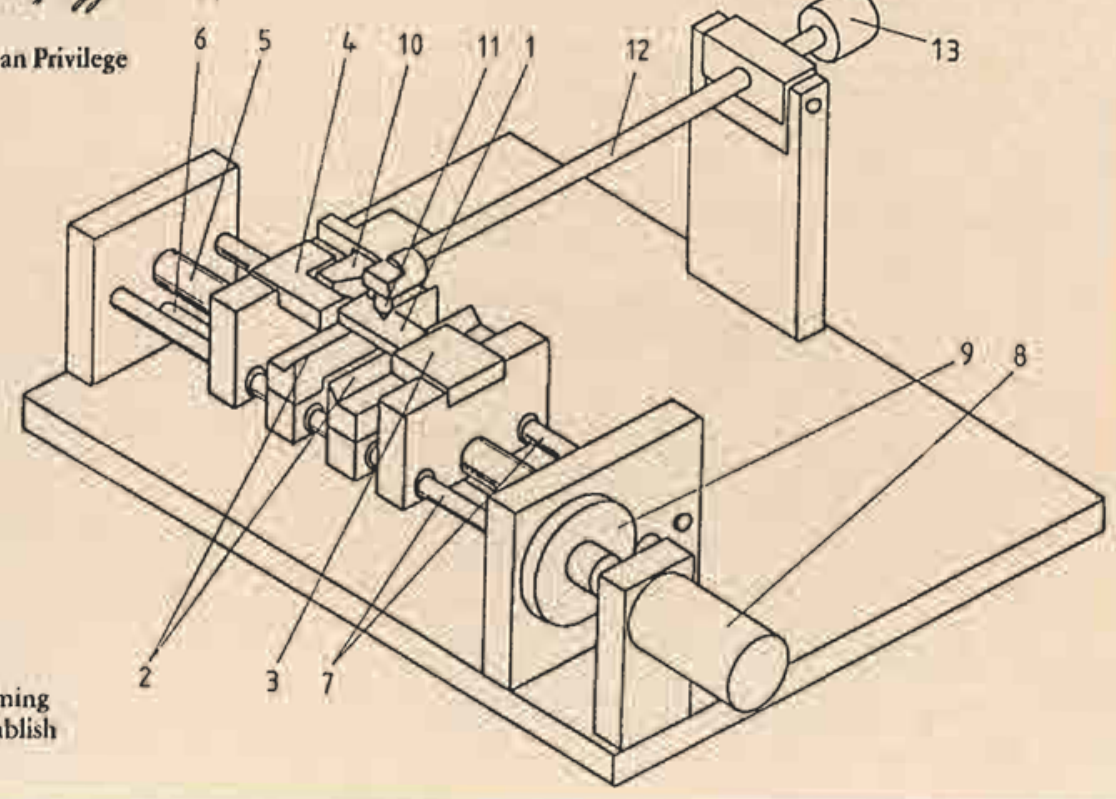




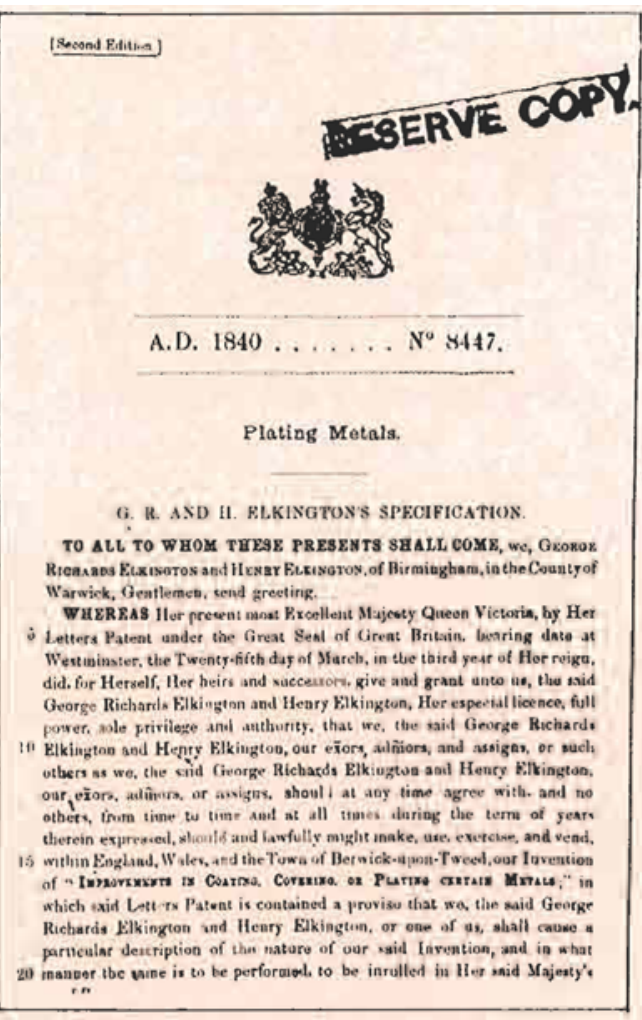

$2 \quad$ A.D. $1840 .-\mathrm{N}^{\circ} 8447$.

F. R.A II. Elkinglon's Imples in I'cating, Carering, or Plating certain Micals. High Court of Chancery within six calendar montha next and immediately after the date of the said in pait reeited Letters Patent, at in anal by the sume, reference being theretuoto bad, will more futly and at latge appear.
XOW $\mathrm{XNOW}$ YE, that in compliance with the said provis, he, the sait Gearge Rieharda Eikington sud Heary Elkington, to hereby deel.uro that the nature of our soid Inventiog, and the manner in which the same is to bo perforined, are full, desseribed and aecortained ia and by the followitr: statement thereot, that in to sy: -

Our Invention consists of four parts, and has teference to several distinet operations, pencensus, or methoils, videlicit :-

Yint, to a method of covering, enating, or plating enpper and bras with silver, by first apylying a conting of tilver to the surface of the onetal to be plated, anul after wards fusing the same thereece, so as to canse the silver to unite and alloy with the uirface of the civited metal, in thonamucrherenfter deveribed. is

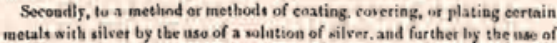
netals with silver by the usso of a wolution of silver. and fur ther by the une of A solution of silver in couaes

Thirdly, to a method or methods of easting, covering, or plating certain metals with gold by the ane of a certain solutius of gold, and farthor by the ise of a solution of gold in connection with the application of a galvanic corrent, at alto horein-afer described. Fourchly, to a metbod of proparing iton so as tin render it better fited firr

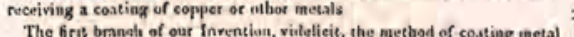
The hrit branali of our Inrentian, vitlalicic, the method of co.sting inetan

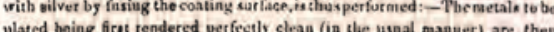

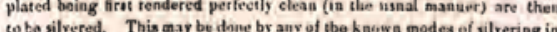

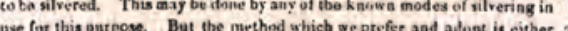
use for this purpose. But the methed which we profer aad adopt is ejther 30

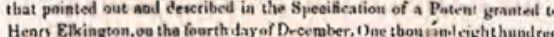

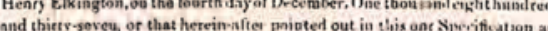

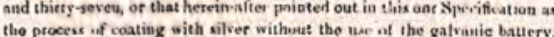

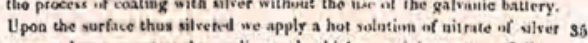
more of less esmentrated aceunding to the thickmest of the coatimg of silver required, which we perfuria by immening the metal to be custed is the

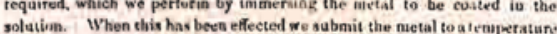
suffieat to expel all the neid, suil leave a merely metallic coating of silver.
Fig. 5

The classic

British Patent

No. 8447

granted to

the Elkington

brothers in

1840 for their

original gold

electro-depostion

process.

Even though only

the first 4 pages

are reproduced

here, a simple

eloquence lost

in modern

publications is

apparent

throughout.
A.D. $1840,-\mathrm{N}^{\circ} 3447$.

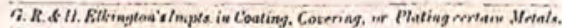
This takea place when the metal is brought to a state a little lielow reet heat. and nay be aceertained by observing whea the surtace of the inetal assumes a whitiath ap,earatice. The artinle is then feady fort the procees of fosion, which are perform in the manner following:-Take a sufficient quantity of calcined S borax and put in into a suitable vasual The veseel which we ne for this purpose in of caut iron mule after the shape of a ghlass maker'o prit and beated by a surnounding tue. In this venel the botax is tin be fuact, the tomperature being rnised antit the borar becones quite fluid and of sutficent heat to melt silver, whiel may bo axcertained by imnsersing therein a piece of wetal coated with silver. The time repuirest to effeet perfect fusiob of the vilver vill ilepend parilyna tho teraperature of the molten birax and partiyon the aature of hae work to be doos; if the articles are wi thin wrought metal

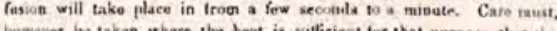

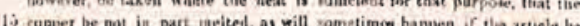

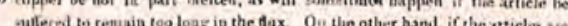
masive

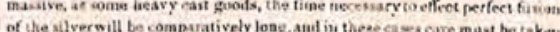

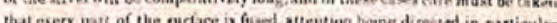

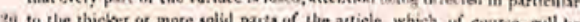

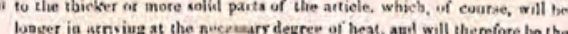
last to five. This the workman will reudily ascertain by liniug tho the

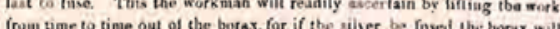

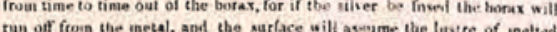

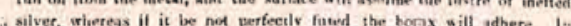

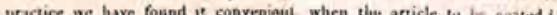

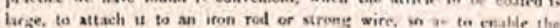

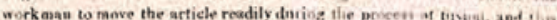

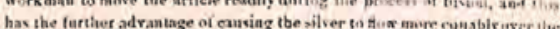

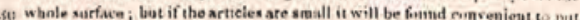
a aunber of them cogether into a shallow bavket inarle of atting imm nut put

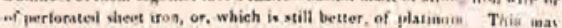

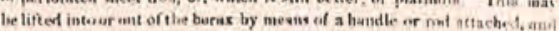

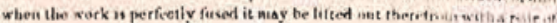

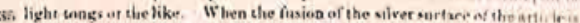

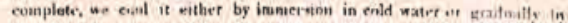

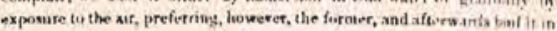

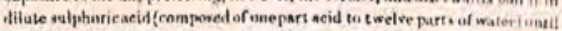

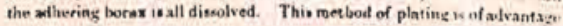

\section{$4 \quad$ A.D. $1840,-\mathrm{N}^{\circ} 8447$}

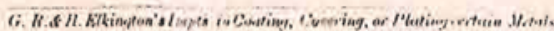

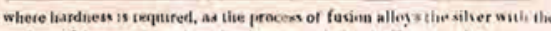
surtace of the copper, and reaters it extromely bard. For a tmish to iaprem.

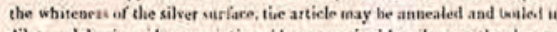

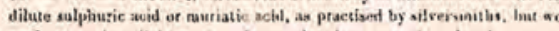
prefer to apply a thight cuating of pure silter ligneusus of a galvauic carrewt,

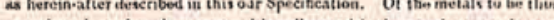

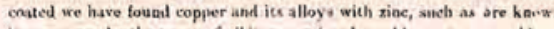

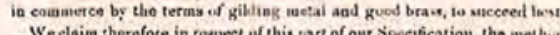
We clain therefore, in respect of this part of our spocitication, the methid

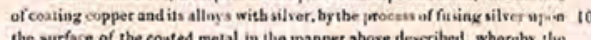
the surface of the couted metal in the manaer nbove described, whereby the costiog of silver is alloged or united with the surlace of the conted mital. Theicor

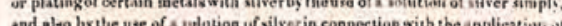

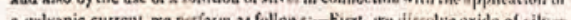

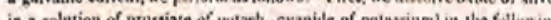

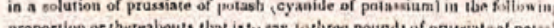

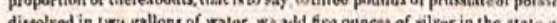

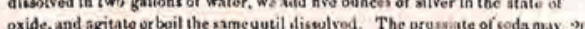

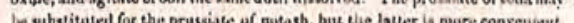
The solution thus prepared is the ready for use. The aricles to be cons being firos rendured perfectly free ifrom acale or

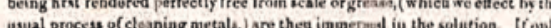
a alight covering of silver ie required, as in ordinary silvering. we prefer to

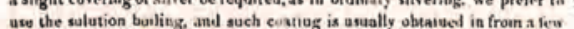
weconds to a mianta. For this degres of cuatiog the applicatiou of the galvanic battery is not required. But, tesondly, if a thicker casting of silver

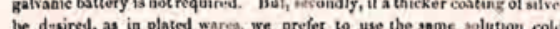
aud obtain s thicker deposit of aiver by the application of a galvanie current. The retbods of prod ucing and applyiug galvanic earreuts are various most riuplo with which wo are acquainted is contast with a bar of metall. zise or other eleetro-positive metal. A membranuas or purvus diaphrage.

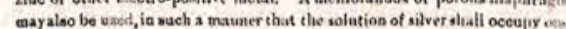
side, aud a dissigilar fuid the other ; but we have founal that the unust 3 effeient and convenieat for the purpose alowo bentioned are nome form.

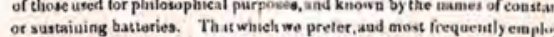
cosenits of two concentric cylinaters closed at the bothom, the nater obe af 


\section{Electrodeposition of Gold}

As some 60 per cent of the present day non-dental industrial usage of gold involves gold in the electrodeposited form, it is perhaps fitting that we should dwell briefly upon an historic British Patent, No. 8447 granted in 1840 to the brothers George and Henty Elkington which was not only the first unambiguous exposition of the aqueous electrolytic deposition of gold but also helped to lay the foundation for the modern electroplating industry. Little, one imagines, did the Elkingtons guess that their landmark patent, almost 150 years ago, would give birth to one of the most competitive and highly patented technological fields in modern times.

As with the Austrian privileges discussed earlier the Elkington gold plating patent reveals an eloquence seldom seen in its modern counterparts (Figure 5).

\section{Modern Patents as an Information Source}

The European patent application referred to above takes us right into the modern patent scene and there we find that the patent information available falls far short of being fully used. This is due to a number of misconceptions touched upon earlier, and also to the fact that patents frequently are written in a legal jargon referred to as 'patentese'. A further factor is that to $\mathrm{R} \& \mathrm{D}$ personnel they are often not as readily available as is the journal literature. However, many developments of technical importance are published as patent documents, and only a surprisingly small fraction of these appear later in scientific and rechnical journals (3). A look at Japan with its impressive technological revolu tion which took place over the past several decades, and which, as it developed was considered to be due largely to copying, shows how this country made and continues to make extensive use of patent information, and does not attempt to deny this. This is evident from the words by Dr. Masaru Ibuka, 9th President of the Japan Institute of Invention and Innovation (JIIl) who said:

'Japan's economy developed remarkably after World War II, very much as a result of progress in science and technology. However, this progress, as is commonly known, depended upon research and development based on technology transfer from the advanced countries of Europe and America. It was not the outcome of Japan's original research and development. Today, Japan ranks with the other advanced countries in science and technology'.

Nowadays, Japan is the most prolific single contributor to the patent literature, a phenomenon for which the name 'Japanese Penetration' has been coined. Besides this, and apart from the language problem, the Japanese patent system presents its own difficulties to the rest of the world, which will become apparent below.

If we consider inventions relating to gold usage, Tables I and II give interesting figures of published patent documents over the period 1980-1984 under the IPC (International Patent Classification) Subgroups C22C 5/02 (alloys based on gold) and C25D 3/48 and 3/62, (electroplating of gold and gold alloys) (5).

In terms of the number of patents published, Japan today is the
Table 1

Published Patent Applications for the IPC Subgroup C22C 5/02 (Alloys Based on Gold)

\begin{tabular}{l|c|c|c|c|c|c}
\hline Year & 1980 & 1981 & 1982 & 1983 & $\begin{array}{c}1984 \\
\text { up to Sept. }\end{array}$ & $\begin{array}{c}1980-1984 \\
\text { Total }\end{array}$ \\
\hline $\begin{array}{l}\text { World excluding } \\
\text { Japan }\end{array}$ & 16 & 10 & 2 & 14 & 7 & 49 \\
Japan & 27 & 18 & 11 & 20 & 56 & 132 \\
Total & 43 & 28 & 13 & 34 & 63 & 181 \\
$\begin{array}{c}\text { Japanese } \\
\text { penetration } \\
\%\end{array}$ & 63 & 64 & 85 & 59 & 89 & 73 \\
\end{tabular}

Table II

Published Patent Applications for the IPC Subgroups C25D 3/48 (Electroplating of Gold) and

C25D 3/62 (Electroplating of Alloys Containing More Than $50 \%$ by Weight of Gold)

\begin{tabular}{l|c|c|c|c|c|c}
\hline Year & 1980 & 1981 & 1982 & 1983 & $\begin{array}{c}1984 \\
\text { up to Sept. }\end{array}$ & $\begin{array}{c}1980-1984 \\
\text { Total }\end{array}$ \\
\hline $\begin{array}{l}\text { World excluding } \\
\text { Japan }\end{array}$ & 36 & 25 & 19 & 20 & 17 & 117 \\
Japan & 13 & 17 & 26 & 14 & 7 & 77 \\
Total & 49 & 42 & 45 & 34 & 24 & 194 \\
Japanese \\
$\begin{array}{c}\text { penetration } \\
\%\end{array}$ & 27 & 40 & 58 & 41 & 29 & 40 \\
& & & & & &
\end{tabular}

most active contributor to the world patent literature. However, the significant Japanese penetration, which is evident from Tables I and II needs some qualification. For instance, the 56 Japanese publications describing new gold-based alloys against 7 from the rest of the world during the first 9 months of 1984 contain a large number of variations on one theme. Thus the Japanese Unexamined Applications

$\begin{array}{ll}\text { JP 59-100237 } & \text { JP 59-107045 } \\ \text { JP 59-100238 } & \text { JP 59-107046 } \\ \text { JP 59-100239 } & \text { JP 59-110743 } \\ \text { JP 59-100240 } & \text { JP 59-110744 } \\ \text { JP 59-100241 } & \text { JP 59-110745 } \\ \text { JP 59-100242 } & \text { JP 59-110746 } \\ \text { JP 59-100243 } & \text { JP 59-110747 } \\ \text { JP 59-100244 } & \text { JP 59-110748 } \\ \text { JP 59-107042 } & \text { JP 59-110749 } \\ \text { JP 59-107043 } & \text { JP 59-110750 }\end{array}$

JP 59-107044 
were all filed by Tanaka Kikinzoku Kogyo Limited. These applications have almost identical texts and all deal with materials for electrical sliding contacts, in which to a number of basic gold alloys are added varying amounts of other elements. This practice of filing separate patent applications obviously inflates considerably the number of published documents and therefore statistics such as those given in Tables I and II which indicate an impressive domination by Japanese documents should be read with appropriate care. Incidentally, the prefix 59 in the above patent numbers is the Showa number, indicating the year of the present emperor's reign. (Showa numbers are converted into Gregorian years by adding 1925 , i.e. $59+1925=1984$ ).

The Japanese 'one claim one patent' principle is also the reason why in patents or patent applications filed by Japanese applicants in other countries multiple priorities are frequently encountered: in these cases a number of separate Japanese documents have been condensed into one application conforming to European or American standards

Tables I and II also show that the actual number of annually disclosed inventions describing gold-based alloys, and new processes and techniques for electroplating gold are quite manageable. The number of actually published documents is, of course, considerably higher, due to equivalent patents being filed in various countries. Nevertheless, such 'Patent Families' substantially increase the information value of the patent literature because frequently applications filed in different countries offer one document translated into various languages (sometimes with minor differences due to differing national patent laws).

\section{Sources for Patent Information}

There are definite signs that patent awareness is on the increase. We need only look through the reference lists of many recent papers to confirm this. For example, in the review paper on electroless gold plating by H.O. Ali and I.R.A. Christie published in a recent issue (October 1984) of Gold Bulletin, not less than 20 out of 60 references, or 33 per cent, are patent publications. This increase is due to the fact that today patent information is more readily obtainable than hitherto as a result of the development of patent information services, the efficiency and sophistication of which were well demonstrated at the recent WIPO (World Intellectual Property Organisation) First Patent Information Fair (4). Services such as the International Patent Documentation Center, (INPADOC), Derwent, Chemical Abstracts, Pergamon Infoline, Mead Data Central and CLAIMS not only allow the identification of patent publications in certain fields via a computer terminal, but certain data banks can be searched for patent families and even the legal status of patents. Knowledge of the latter can be of the utmost importance and benefit as is illustrated by the following.

Patents can be valid for periods of up to 20 years. However in many countries annual renewal of them is required. Because of this and the costs involved, many patents expire long before their possible lifetime. Thus the average legal validity of patents in the Federal Republic of Germany, for instance, is estimated to be only about 3 years! The information contained in patents which have expired can be freely used anywhere.

Apart from the patent information services mentioned above, there are published comprehensive reviews of the patent literature in specific fields. Examples which can be mentioned are the 'Chemical Technology Reviews' by Noyes Data Corporation (6) and the 'European Patent Office Applied Technology Series' (7). The current patent literature relating to gold usage in science and technology is covered in 'Gold Patent Digest', published quarterly by the International Gold Corporation.

With the availability of these and other services for patent information, and copies of the original documents being readily available from patent offices and patent services, the patent literature including that describing new gold technology and uses should gradually assume its proper place as a source of technical and scientific information.

\footnotetext{
References

1 New Scientist, 1984, 103, (1419), 25

2 P. Ritter von Beck; Das Osterr. Patentrecht Carl Heymanns Verlag, 1983, p. I20

3 F. Liebesny et al., Inf. Sci., 1974, (Dec.), 165-177

4 lst WIPO Patent Information Fair, Geneva, September 26 and 27, 1984

5 Data extracted from material supplied by INPADOC

6 'European Patent Office Applied'Technology Series', Vols. 1-8, Pergamon Int. Inf. Corp., VA., U.S.A., 1984

7 'Chemical Technology Reviews', Many volumes, Noyes Data Corporation, NJ., U.S.A.
} 